\title{
Metabolic reprogramming by KSHV in cellular transformation
}

\author{
Ying Zhu*, Suzane Ramos da Silva, Shou-Jiang Gao \\ From Metabolism, Diet and Disease 2014: Cancer and metabolism \\ Washington DC, USA. 28-30 May 2014
}

Oncogenic Kaposi's sarcoma-associated herpesvirus (KSHV) is causally linked to several human cancers including Kaposi's sarcoma and primary effusion lymphoma. Despite intensive studies, little is known about how KSHV alters cellular metabolism during cellular transformation. Using a novel model of KSHV-induced cellular transformation of primary rat embryonic metanephric mesenchymal stem cells (MM), we found that KSHV-transformed MM (KMM) cells did not require glucose for growth and formation of colonies in soft agar. Consistent with these results, KMM cells had lower levels of glucose consumption, lactate production, oxygen consumption and intracellular ATP levels. Compared to MM cells, KMM cells had lower levels of glucose transporters GLUT1 and GLUT3. Genetic deletion of KSHV-encoded microRNA cluster or vFLIP gene from the viral genome, which resulted in reduced NF- $\kappa$ B activity, significantly increased glucose consumption and lactate production, and sensitized the cells to glucose deprivation. Accordingly, inhibition of the NF- $\kappa \mathrm{B}$ pathway with either RelA siRNAs or inhibitor JSH-23 dramatically increased glucose consumption and lactate production. Thus, the insensitivity of KMM cells to glucose is mediated by the heightened NF- $\kappa \mathrm{B}$ activity. In contrast to the insensitivity to glucose, KMM cells were sensitive to glutamine deprivation. Glucose deprivation further increased glutamine consumption of KMM cells. Inhibition of glutamine metabolism with amino oxyacetate (AOA), an inhibitor of glutamate-dependent transaminases, or epigallocatechin gallate (EGCG), an inhibitor of glutamate dehydrogenase (GDH) mimicked the effect of glutamine deprivation and effectively suppressed cell growth and formation of colonies in soft agar. Addition of nonessential amino acid (NEAA) mixture or asparagine alone was sufficient to restore the growth of KMM cells upon glutamine deprivation while dimethyl $\alpha$-ketoglutarate only had partial effect, indicating that glutamine not only provided a carbon source to fuel the tricarboxylic acid (TCA) cycle but also supplied nitrogen for biosynthesis. Taken together, these results indicate that KMM cells depend neither on aerobic glycolysis nor on oxidative phosphorylation but instead on glutamine to support cell growth and transformation. Our findings also suggest that metabolic reprogramming might have a critical role in KSHVinduced cellular transformation.

Published: 28 May 2014

doi:10.1186/2049-3002-2-S1-P88

Cite this article as: Zhu et al:: Metabolic reprogramming by KSHV in cellular transformation. Cancer \& Metabolism 2014 2(Suppl 1):P88.

\footnotetext{
Submit your next manuscript to BioMed Central and take full advantage of:

- Convenient online submission

- Thorough peer review

- No space constraints or color figure charges

- Immediate publication on acceptance

- Inclusion in PubMed, CAS, Scopus and Google Scholar

- Research which is freely available for redistribution

C Biomed Central

(c) 2014 Zhu et al; licensee BioMed Central Ltd. This is an Open Access article distributed under the terms of the Creative Commons Attribution License (http://creativecommons.org/licenses/by/4.0), which permits unrestricted use, distribution, and reproduction in any medium, provided the original work is properly cited. The Creative Commons Public Domain Dedication waiver (http://creativecommons.org/publicdomain/zero/1.0/) applies to the data made available in this article, unless otherwise stated. 